\title{
Aiko Okamoto-MacPhail*
}

\section{The Jesuit Mission in Japan and History of Rhetoric and Its Languages}

DOI: http://dx.doi.org/10.12775/LC.2019.049

\begin{abstract}
This article addresses the works of the Jesuit Mission Press dedicated to rhetorical persuasion. The Society tried to transplant Christian expressions of faith in Japan in Latin and in European Christian paintings, and it met with the indigenous convention of expressions. Because these two expressive conventions are so different, the effect of their interactions sometimes took a turn unexpected by the Jesuit missionaries who stayed in Japan from 1549 to 1639 . To implant Christianity, the Society adopted a holistic approach of building schools and hospitals in order to reach a wide range of population, while Jesuits operated very carefully so that their teaching would not disturb the existing social order in Japan. At the same time, the mission press worked to publish texts with the Christian doctrine, to teach how to say prayers, to explain puzzling aspects of Christianity, and to set the standard for the language to be used as church Japanese. These documents also taught how to survive the proscription.
\end{abstract}

Keywords: the Society of Jesus, rhetoric, Japan, translation, printing press

* Adjunct Assistant Professor in French at Indiana University Bloomington. Her reseaech areas are: 19th and 20th-century French thought, cultural relationship between France and Japan, as well as Jesuit rhetoric in early modern and modern period.

E-mail: macphail@indiana.edu | ORCID: 0000-0003-1874-8941. 


\title{
Jezuicka misja w Japonii a historia retoryki i jej języków
}

\begin{abstract}
Streszczenie: Artykuł jest poświęcony pracom wydawnictwa misji jezuickiej związanym z perswazją retoryczną. Towarzystwo próbowało przenieść do Japonii chrześcijańskie wyrażenia religijne po łacinie i europejskie malarstwo chrześcijańskie, co spotkało się z miejscową konwencją środków wyrazu.. Ponieważ te dwie konwencje wyrażania się są tak różne, czasami efekt ich interakcji był nieoczekiwany dla jezuickich misjonarzy, którzy pozostawali w Japonii od 1549 do 1639 roku. Towarzystwo, żeby wprowadzić chrześcijaństwo, zaadaptowało holistyczne podejście buddyjskich szkół i szpitali, starając się dojść do szerokich kręgów ludności, Jezuici działali przy tym bardzo ostrożnie, by ich nauczanie nie zaburzyło istniejących szkół i porządku społecznego w Japonii. W tym samym czasie drukarnia misji pracowała nad wydawaniem tekstów z doktryną chrześcijańską i uczących, jak wypowiadać modlitwy, objaśniać zagadkowe aspekty chrześcijaństwa i ustanawiać standardy języka używanego w kościele japońskim. Dokumenty te pokazują także, jak przetrwać banicję.
\end{abstract}

Słowa kluczowe: Towarzystwo Jezusowe, retoryka, Japonia, przekład, prasa drukarska

n 1888, when Ernest Mason Satow published The Jesuit Mission Press in Japan 1591-1610, the fact that the Jesuits established a press and published their books in Japan was long since forgotten. For this reason, Satow's book was welcomed as a revelation. Satow's discovery primed the pump of memory about the bulldozing effort of the Society of Jesus, which ended with the tragic suppression of Christianity on the soil in whose fertility they so earnestly believed. Though long forgotten, the Jesuits left many documents. This paper assesses the power of persuasion exercised by these Jesuit documents even after their language had lost its literal meaning for the Japanese.

The printed documents that the Jesuits left behind endow language with physical existence not only in the material shapes of books, but also in the sounds of words. Through reading and recitation, the books published by the Jesuit Mission Press spoke to those who could read and write as well as to those who could not. This visual and acoustic experience of language survived among senpuku kirishitan ${ }^{1}$ under the ban of Christianity, until one day on March 17, 1865 a group of Japanese from Urakami visited the newly constructed Catholic church at Nagasaki and asked French bishop Bernard Thaddée Petitjean: "Sancta Maria no go zō wa doko?² (Where is the precious statue of Saint Mary?)” (Petitjean 2015: 42). My paper argues that Church rhetoric of persuasion tailored for Japan survived the ban of Christianity by bearing a new function similar to memorabilia like a cross or a medal

1 Miyazaki Kentarō proposes to call the Japanese Christians in the Edo period under the proscription of Christianity senpuku kirishitan (lit. Christians in a latent phase), and use the more familiar term kakure kirishitan (lit. Christians in hiding) to designate the Japanese Christians, who after 1873, when the ban was lifted, refused to come back to Catholicism. Those who came back to the Catholic Church after 1873 are called by Miyazaki fukkatsu kirishitan (lit. revived Christians) (Miyazaki 2014: 14, 40). In my paper, I follow Miyazaki's wording.

2 Petitjean recorded these words in the original Japanese. 
and supported Japanese Christians, like a crutch for the disabled, to walk along the arduous path of proscription.

Tani Shinsuke describes this survival of Christianity in Japan as "a miracle in the history of world religion” (Tani 2014: 66) while Miyazaki Kentarō judges that Japanese Christians under the ban preserved only the hollow container of rituals, but forgot what was in it (Miyazaki 2018: 169). If an object such as a book, cross, or medal was worshipped as an end in itself, that constitutes idolatry. In his book entitled Kirisutokyō to gūzōsūhai (lit. Christianity and Idolatry), Asami Masakazu argues that, on the precise point of the flexible accommodation of idol-worship, the notion of God that should be universal became flexible in Japan (Asami 2009: 335). In moral theology, many difficult cases of conscience involving the worship of idols occurred in the District of India that included Japan. This act, prohibited by the Ten Commandments, was assessed differently in India and Japan: while in India, European criteria were applied without compromise with the support of Indian monarchs, in Japan the criteria were loosened in order not to disturb the existing social order by invoking the concept of invincible ignorance and by using the sacrament of confession to forgive sins committed in ignorance. Though confessors qualified by the Catholic Church were no longer available under the ban, the Society left in writing the teaching that sin can be forgiven through the application of contrition.

Asami distinguishes two separate elements in the practice of idol-worship (ibid.: 337). The first is theological and concerns the attitude of the Christian Church to non-Christian religions; the second is the behavior of the idol-worshippers, which is more a question of individual deeds and mental life. To Asami's two elements, I propose to add a third element that is the question of how to express Christian faith. In order to approach God, the Society of Jesus was forced to use an alien style of expression tailored to non-Christian, therefore by definition idol-worshipping, religions. Non-Christian civilizations had established centuries-old conventions of expression that came with their own concept of invisible entities above man. The ultimate difficulty is to convey Christian faith through nonChristian cultural conventions that rule year-round local calendric life, without being led astray into idol-worship.

The Society used two complementary strategies to counter this situation. One is the question of form, that is the Catholic doctrine, and the other is the question of practice, that is the flexible application of the doctrine by knowing which exact cases of conscience can be forgiven and which others cannot. In Japan, the former was done by the Jesuit Mission Press, which printed the textbooks through which doctrine was implemented in the Jesuit educational system. On the other hand, the latter was practiced on the human level, in the teaching of Jesuit schools and the daily exchange with Japanese population in preaching and in church liturgy. Both together, they transplanted European conventions of expression to Japan. The effort of teaching Latin to young Japanese pupils was part of a wider effort of inculcating belief through painting, music, and other European expressions of faith. It is only through such expressions that the Society could explain their belief. This gave rise to the confusion of the content of the faith with its expressive means.

Before starting our demonstration, we will look at an example of Jesuit accommodation. In Japan, the Society of Jesus operated very carefully so that their teaching would not disturb the existing social order. For example, in the relationship between master and servant in feudal Japan, the Society approved that the servants can assist their master's service 
in the Buddhist temple provided that they only show respect to their master as their secular duty orders it without worshipping the idol in the temple. Many Japanese cases of conscience were gathered in an anthology by Alessandro Valignano S.J. (1539-1606), the Visitor of India, in the form of questions to European universities, and Valignano emphasized that the answers he got from theologians were discussed in the Congregation of the Cardinals and approved by Pope Clement VIII (pope 1592-1605). With a letter from the Superior General of the Society of Jesus Claudio Aquaviva, the Vatican answers were dispatched to Japan, and in April 1597 Valignano received them in Macao, and then these answers reached Japan around 1598 (Asami 2009: 148). With the papal seal of approval, the Society practiced their accommodation in Japanese cases of conscience.

The theological basis of this accommodation was the doctrine stipulated in the Council of Trent as Roman Catechism, approved in 1566 by Pius V and in 1583 by Gregory XIII, and published as the Doctrina in Japanese in Amakusa circa 1591 by the Jesuit Mission Press (Valignano 1990: 13, note 5). On the foundation of this theological principle, accommodation was applied in administering the sacraments in Japanese Jesuit churches. Pedro Gomez S.J., the vice provincial of Japan, wrote a Compendium for the Japanese Society ${ }^{3}$ that was published in Latin in 1593 and in Japanese in 1595 (Asami 2009: 158). Part Three entitled De Theologia is based on the Catechism of the Council of Trent (Gonoi 2012: 129; Asami 2009: 198, note 39), but at the same time it reintegrates the Japanese cases of conscience into theology (Asami 2009: 160-168, 335). We call this flexible doctrine approved by the Vatican and presented in the series of publications by the Jesuit Mission Press the Christian doctrine in this paper.

This doctrine was taught by two means, the Jesuit educational system and the Japanese translation of books by the Jesuit Mission Press. These two activities can be understood in the larger context of the Jesuit mission. The Jesuit notion of eloquentia perfecta defined by Cinthia Gannett encompasses "erudition, wisdom, virtue, and eloquence as an integral whole" (Gannett 2017: 678) to persuade people to believe in Christianity. True to this ideal of unifying all possible fields of expression for the single purpose of persuasion, the Society practiced a holistic approach in Japan. In a country where the Jesuits were a minority within the majority culture dominated by Buddhism, the Jesuit rhetoric of eloquentia perfecta could not help but be more holistic than in Europe where, during the Christian century of Japan, a wide range of arts and sciences constituted the Jesuit school curriculum. The Society adopted the expanded version of eloquentia perfecta in Japan by building hospitals and shelters for the poor and orphans in order to welcome a larger population than those who came to churches and schools. Among the wide range of their activities, medical science left perhaps the most lasting mark with the practice of a European medicine ${ }^{4}$. This means that Christian forms of expression survived in Japan not as religion but as science. Both religion and science work for the universal principle that sets the rule in the perceived world.

The Jesuit mission stayed in Japan for a relatively short period of time. The Catholic mission with papal approval started with Saint Francis Xavier's arrival at Kagoshima

\footnotetext{
3 The full title is: Compendium catholicae veritatis, in gratiam Japponiorum fratrum Societatis IESU, per R. Patrem Petrum Gomezium V. P. Societatis IESU in provincia Japponica.

${ }^{4}$ Astronomy is another field that left its mark. However, European astronomy before Copernicus and Galileo was strongly connected to Christianity, and its implementation in Japan was done with maximum effort to erase its Christian character.
} 
in 1549 . The mission ended in 1639 when the government of the shogun finalized the proscription of Christianity. In that short span of activity that lasted for ninety years, called by Charles Ralph Boxer the Christian century of Japan, the active period of the Jesuit press was even shorter. The European style printing press with movable type was brought to Japan in 1590 and it was shipped out of Japan in 1614. In less than twenty-five years of activity, the Jesuit press played a crucial role in the spread of Christianity as well as in the history of Japanese printing and book publishing that created a classic like Aesop's tales, which are so deeply naturalized in Japan that the Japanese today have trouble separating them from their own native tales.

The number of books known to have been published by the Jesuit Mission Press is still increasing. The seminal book by Ernest Satow The Jesuit Mission Press in Japan 1591-1610 lists only fourteen books. The publication of Tenri Central Library in 1973 lists thirty-one books according to their criteria of classification (Tenri Toshokan 1973: 160-161). In 2012, Gonoi Takashi counts thirty-two existing books with the caution that the Jesuit Mission Press published many more from 1590 to 1614 (Gonoi 2012: 181). The lost books include Saint Ignatius of Loyola's biography written in Japanese. If we count the books published in Macao, Goa, and Lisbon, there are forty-one books credited to the Jesuit Mission (Toyoshima 2013: 1-6).

The publications by the Jesuit Mission Press can be divided into three categories. The first is publications related to Christian doctrines and spiritual life. This category included the instruction of science. The second is publications on language such as dictionaries and grammars in Latin, Portuguese, and Japanese. The third is lay publications including Aesop's tales, poetry, and military tales. One aim of these publications was to create a Japanese literary style equivalent to Church Latin, which we may call Church Japanese, appropriate for doctrinal manuals and spiritual guidebooks and also for preaching in public. For that purpose, the high literary style of written Japanese as well as the respectable style of spoken Japanese, appropriate to secure the good standing of Christianity in Japanese religious culture, was indispensable. The Jesuit Mission Press worked to establish that Christian language in Japanese, at the same time as teaching Latin to Japanese members.

In order to establish its rhetoric, the Society first needed to create an appropriate language. The Society adopted Japanese conventions of expression and tried to situate itself in relation to them. João Rodrigues Tçuzu (ca. 1561-1634), who wrote the Japanese grammar Arte da Lingoa de Japam published at Nagasaki in 1604 by the Jesuit Mission Press ${ }^{5}$, distinguishes two types of written Japanese, Naiden and Gueden, and explains that the former is the style of Buddhist sutras and other Buddhist writings while the latter is the secular writing style (Rodrigues 1955: 661). He concludes that the Jesuits should learn the respectable high style that is understood without difficulty by a wide Japanese public (ibid.: 664). The publication of two military tales by the Jesuit Mission Press confirms that his advice was put into practice. For, in his Arte da Lingoa de Japam, Rodrigues distinguishes two styles inside the genre of fiction called monogatari: the solemn style of historical tales like The Tale of the Heike, The Tale of the Heiji War, and the Taiheiki on one hand, and the elegant style of narrative (sōshi) on the other (ibid.). The Jesuit Mission Press printed two historical tales, The Tale of the Heike and the Taiheiki. This choice shows that the Society promoted

\footnotetext{
${ }^{5}$ We use Doi Tadao's Japanese translation, Rodrigues Nihon daibunten (Tōkyō: Sanseidō, 1955).
} 
the solemn style that characterizes historical narrative, chanted or narrated with melody, for a large Japanese public.

The Tale of the Heike, published in 1592 at Amakusa, narrates the war between the Genji and the Heike from 1131 to 1191, in Japanese language printed in Roman script. This tale is the most famous among the medieval historical tales that represent the Buddhist view of the ephemeral world, chanted by the blind bards with biwa guitar. As for the excerpt of Taiheiki, the date and the place of this Jesuit publication are not known; but it must have been published between 1598 and 1614 (Kawai [\&] Muramoto 1973: 157) because the excerpt of the Taiheiki existing today is approved by Manoel Barreto S.J. (in Japan 15901620) and L. de Cerquiera (bishop in Japan 1598-1614) and probably after 1611 (Gonoi 2012: 132). The Taiheiki, which narrates the period between 1318 and 1367, was first appreciated by the warrior daimyos of high rank through its commentaries and explanations called taiheiki-yomi, then popularized by the itinerant story-tellers performing in the streets with the bamboo flute shakuhachi (Wakao 2003: 280-281). From the sixteenth century throughout the Edo period (1600-1868), the Taiheiki framed the concept of history, and the modern discipline of history started with criticism of the Taiheiki (Nitta 2001: 8-10). The Jesuits published their excerpt of Taiheiki as the epitome of the best writing style, and as such it was presented as the ultimate goal for those who were learning the Japanese language (Gonoi 2012: 132).

The Jesuit translators also consulted Buddhist texts. The Contemptus mundi jenbu (jenbu means the complete translation) published in 1596 and its abridged re-edition Contemptus mundi in 1610 are books of devotion that invite a reader to a personal meditation. The original of this book is De Imitatione Christi attributed to Thomas à Kempis (1380-1471) ${ }^{6}$. William J. Farge S.J. conducted a refined textual comparison between the original Latin and the two editions of the Japanese translation of De Imitatione Christi. The Jesuit Mission Press prints the second part of the title Contemptus mundi first, whereas in Europe, Kempis' book is known by the first part of the title De Imitatione Christi. In this choice of title, Farge reads an intention of the translator to talk to the Christian proselyte by adapting the original De Imitatione Christi. Of the three stages of meditation on the way to spiritual perfection (the notion first proposed by the sixth-century religious writer Dionysius the PseudoAreopagite), the Japanese title Contemptus mundi represents the first stage of meditation for beginners, while the more familiar title De Imitatione Christi corresponds to the second and third stages (Farge 2002: 28-29). Farge continues that, even though this differentiation of three stages became less clear in the European Middle Ages, the difference between contemptus mundi and de imitatione Christi "was quite clear in Jesuit spirituality" because it was "constructed by the founder of the Jesuit order, the Basque nobleman Iñigo de Oñaz y Loyola (1491-1556)" who was inspired by Thomas à Kempis’ De Imitatione Christi (Farge 2002: 29-30).

\footnotetext{
6 The second edition in particular shows a lot of editorial realignment and abridgement of the first Japanese edition and of Kempis' original book. Toyoshima suggests that the Japanese translator took Luís de Granada's Spanish version for the textual basis of translation (Kirishitan to shuppan, p. 8-9). In his own copy of Satow now in the collection of the Lilly Library of Indiana University, C. R. Boxer writes in the margin on page 29 of The Jesuit Mission Press. 1591-1610 that the Japanese title is based on "Fray Luís de Granada, Obras, Madrid 1788, tom VI p. 481" and comments: "This seems conclusive as to the use of his version in preparing the Japanese." A further study is necessary as for the relationship among Kempis, Granada, and two Japanese editions.
} 
To convey this path to meditation at the heart of Jesuit spirituality, the translator used Buddhist vocabulary to appeal to the reader. In both Contemptus mundi and Guía de Pecadores, the translator, whom Farge identifies as a Japanese Jesuit Martinho Hara (ca. 1570-1629), who was one of the four Japanese of the Tensho Mission, used "a vast majority of Japanese words [... of Buddhist origin," of which twenty-five to thirty Buddhist terms became the set vocabulary to transmit Christian concepts (Farge 2002: 80). Yet, the translation carefully avoids an easy syncretism and stands firm on the ground of Christian tradition. For Farge, "[ $\mathrm{t}$ ]he methodology of the mission press lies firmly in the European medieval tradition of imitation" (ibid.: 79). That medieval tradition of imitation consists of maintaining the "exact pattern of the original" in form, while the translators are "free to adapt or revise the content and modify the authorial intention for their own purposes" (ibid.).

In the second edition of De Imitatione Christi in 1610, with which the translator took more editorial freedom, the written style of Japanese language is what we call gago or elegant language originating in the canonical masterpieces of the Heian period (794-1185) written in a fine woman's hand and filtered through the Japanese medieval essays of Buddhist tradition ${ }^{7}$. The rhetoric of persuasion is very powerful because the style chosen by the translator comes with a whole cultural baggage of main-stream Japanese literature and thoughts that take for their theme the passing nature of the world that orders contemptus mundi. Yet, this Buddhist perspective of after life that puts emphasis on the communion with nature is converted into the vertical aspiration of Christianity that looks upward to an unattainable height. What Rodrigues Tçuzu stipulates as the style of written Japanese that the Society should adopt, a respectable fine language understood by all, is exemplified by this translation.

The establishment of good Japanese was essential to position Christianity as a religion equal and even superior to Buddhism. The printing press was planned in its early stage to produce textbooks, and from the beginning it was designed to print also in Japanese script. Arai Toshi quotes Valignano's letter ordering from Europe the movable type fonts in Roman letters (Arai 1973: 16), but she does not mention the movable types of Japanese characters also made in Europe. Even the most literate lay Japanese did not read the Roman alphabet, and it was necessary to print books in the Japanese writing system. It is Toyoshima Masayuki who proved that not only the Roman fonts but also the Japanese fonts of phonetic kana and a limited number of kanji (Chinese characters used to write Japanese since around the third century A.D.) were made in Europe and brought to Japan by the Tenshō Mission (Toyoshima 2013: 138-149). Toyoshima adds that the only member of the Tenshō Mission who was able to write the Japanese alphabet with a fine hand of calligraphy while they were in Europe (all others received more Latin education) was Jorge de Loyola. This Japanese youth known only by his name of baptism was an attendant of the four young mission members, and he died in Macao in 1598 on his way home (ibid.: 149).

This fact proves that from the beginning of the printing press in Japan, Jesuit publications were designed to reach a literate public at large in order to introduce a Christian way

\footnotetext{
7 The representative examples are Hōjōki written by Yoshida Kenkō (c. 1153-c. 1216) and Tsurezuregusa (Essays in idleness) by Kamo no Chōmei (c. 1282-1350). See Essays in idleness and Hōjōki, tr. M. McKinney (London, 2013).
} 
of seeing the visible and invisible world. These books published by the Jesuit Mission Press had a lasting influence. Only a limited number of books were printed, probably about one to two thousand copies for each book (Yagi 2013: 300), but once out, these books were read out loud, recited, and the important points were selected and copied by hand, and circulated in hand writing to a wider population (Orii 2013: 189) ${ }^{8}$. Certainly these books were destroyed during the intense period of proscription in the Edo period and their influence was almost totally suppressed. But Japanese Christians, hidden under the ban, kept Christian writings in many cases copied by hand. We should also take into account that in 1590 , when the mission press started to print with movable type, printed books in general, even ones printed with the traditional technique of wood blocks, were rare even among the literate population. Printing had not yet reached the stage of popular press.

In that general historical situation, the Jesuit writings, often copied by hand from the printed versions, were transmitted as tightly hidden tokens of faith. Gonoi writes that as late as in 1790 to 1795, when Japanese Christians were discovered in Urakami close to Nagasaki in the southern island of Kyushu, they maintained their faith with the book of martyrdom, copied by hand, whose content is reminiscent of one of the first two books published by the Jesuits (Gonoi 2012: 26-28). The senpuku kirishitan memorized the wording of prayers without understanding their meaning, because the act of recitation itself became a meaningful goal (Miyazaki 2014: 77). Moreover, for the written documents that Petitjean found in the nineteenth century, the material shapes of writing may have been meaningful in themselves. The Bible was neither translated nor published by the Jesuit Mission Press. Around the world, Christians handle the Bible with care and veneration. If the Japanese Christians could not read or understand the language with many Latin words transcribed in Japanese phonetic alphabet, the Jesuit writing itself was the object of veneration. If a holistic approach of hospitals, schools, and printing press was necessary to persuade the general public to believe in Christianity, the Jesuits also needed to teach Latin to their Japanese members. Even to the majority of the public who did not learn Latin in a structured way, the Jesuit Mission Press successfully found a way to convey uniquely Christian concepts by using the Latin and Portuguese terms transcribed into Japanese phonetic alphabet copying the original European pronunciation. The Christian terms in Portuguese contricão (contrition), sacramento (sacrament), and confissão (confession) or in Latin ecclesia (church) and anima (soul) are some examples. Their meanings were not always clear if no one explained them. The very act of reciting the prayers with these Latin terms, like an incantation, became meaningful, subsequently, in a way that the Jesuits could not foresee.

The installation of the printing press came right after Toyotomi Hideyoshi's expulsion of Jesuit fathers in 1587 followed by the martyrdom of the twenty-six Christians at $\mathrm{Na}$ gasaki in 1596. The Jesuit Mission Press prepared the Japanese public for the time when the Jesuit fathers would not be readily available to explain Christian doctrine. The Doctrina Christiana written by P. Marcos Joreges S.J. (1524-1608) (Cieslik S.J. 1983: 12) was translated into Japanese twice in two different editions in 1591 and 1600. The first edition, printed in Japanese transliterated into the Roman alphabet, was probably intended for Japanese people learning Latin and European Jesuits learning Japanese. The second edition, printed

8 Orii argues that Japanese Christians maintained the essence of the doctrine promulgated by the Council of Trent under the Christian proscription. 
in Japanese writing, could reach a wider readership than the first Doctrina. Both editions explain the Christian doctrine in dialogue. In the Doctrina, the students ask questions and the teacher answers, the opposite of European catechism. Ernest Satow was so surprised with this topsy-turvy dialogue that he wrote: "I have not been able to find any catechism of that period constructed on such a model" because "the questions are put by the catechumen and the answers are given by the catechist" (Satow 1992: 39). The motive was probably to explain Christianity to the curious public who asked many questions. With the book, the students could continue to ask questions and converse with their teachers in the book.

In the Doctrina, Christian doctrine is comprehensively explained in dialogue form ${ }^{9}$. By using this book a catechist can explain: 1) the meaning of the word "doctrine" and 2) the meaning of the cross; say the prayers 3) "Pater noster", 4) "Ave Maria", 5) "Salve Regina", and 6) "Credo"; explain 7) the meaning of each of the ten commandments, 8 \& 9) the Laws of the Church, 10) the Seven Deadly Sins, 11) the Seven Sacraments of the Holy Church, and 12) other things important to know concerning the word "Christian" (Satow 1992: 38-39). This book can serve as a manual of preachers. The catechists need a special training to be able to explain the Latin words transcribed phonetically into Japanese, for example "Deusu" in Japanese for "Deus" and "Kurusu" in Japanese for the cross, in a language accessible to those who are new to Christianity. Even a novice preacher can preach convincingly, especially if gifted with an art of performance, by reading the Roman alphabet of Doctrina. This Doctrina Christiana also covers almost all basic Christian prayers. This book was brought to Japan in 1568 and it was used first in hand-written copy from 1570 (Gonoi 2017: 153). Under the proscription, for those who could read, its translation could also work as a handbook of Christian doctrine.

These printed books were used as textbooks in Jesuit schools. In order to compete with the education given in Buddhist monasteries and temples, the Society started its own schooling system in Japan. The Jesuit project of schools in Japan is divided before and after the first visit of Alessandro Valignano in 1579. In his Sumario, Valignano sketched a complete system of education from the young age to the ordained priesthood. Although his plan would not always be executed later on due to the social and academic conditions under the proscription, his project built the backbone of the Jesuit educational system. The Seminario accepts young children preferably from good families and gives them an intensive education of Latin language, music, and Japanese reading and writing. Of these students, those who choose to be the members of the Society advance to the Noviciado, then to the Collegio. In 1581, there were professors of Latin, Logic, and Japanese, and five students in this college. None of the five students were Japanese, among whom we find the name of João Rodrigues Tçuzu (Gonoi 2012: 122-123); he came to Japan when he was fifteen or sixteen and later wrote books on Japanese language, grammar, and the history of the Japanese Church.

The schooling system implemented the comprehensive structure of thought that formed the European Renaissance. The Society embraced sciences within its structure of expressing the faith. In the Renaissance Jesuit schooling system, Christianity and sciences were taught for one and the same purpose of explaining the invisible principles that set the rules of the human world. This rational and scientific principle of truth hidden in the phenomenal world had the rhetorical function of proving the superiority of European

\footnotetext{
9 Cieslik, Kamei, and Kojima published the complete transcription of this book into Japanese writing.
} 
knowledge of truth. This rational structure of thought remained after the Jesuit mission left Japan.

A Japanese historical document of censorship from 1624 to 1655 (Miyazaki 1968: 342-346) tells us about the college curriculum explained by the apostate Jesuit Giuseppe Chiara (1602-1685), who became the model of the novel translated as Silence written by the Japanese Catholic author Endō Shūsaku. To explain the Jesuit curriculum, Chiara starts with "Latin" after "Reading" and explains that even Europeans need twelve to thirteen years to study Latin, but after its mastery, it becomes much easier to learn many subjects. Then in the order of Chiara's explanation, "Grammatica" is the discipline that teaches how to compose sentences in Latin. "Humanidate" is more advanced than "Grammatica" in Latin, for "Grammatica" teaches how to write a letter to friends, but "Humanidate" teaches the art of writing to a nobleman with literary quotations. "Rhetorica" is the discipline that teaches still more advanced Latin than "Humanidate" because it instructs how to argue in a logically coherent manner to advance Christianity. In "Philosophia", the students learn the principle of all things in the universe in four years, but it does not explain the after-life. "Logica" is the introduction to "Philosophia", and "Casus Conscienciae" examines the ethical conduct. As for "Theologia", it is the study of God and it takes four years. "Lei Canones" is the art of government, not the priestly administration; but it is, according to a note added by a Japanese official, the study for bushi. "Medicina" is the medical study, and "Chirurgia" is the study to become a surgeon. "Arithmetica" is the art of calculation that is not related to the abacus. "Mathematica" is astronomy, and "Astrologia" is also astronomy. "Physiognomia" teaches how to read people's facial expressions. "Cosmographia" is cartography; "Poesia" is the study of poems; "Militia" teaches military strategy; and "Pilotagem" is the art of navigation for the ship pilot. What Chiara is explaining is the truly comprehensive curricula of European Renaissance Humanism.

As the first textbook published for a Japanese college, the Compendium catholicae veritatis of Pedro Gomez mentioned above contains more than the theology that is explained in Part Three. The first two parts of this book cover what the Society thought appropriate as European sciences from the vantage point of the 1590 s when Galileo was still relatively obscure. Of the three parts of the Compendium, Part One is on astronomy and physics, Part Two is on anima or the soul, and Part Three is on Christian doctrine. The first college lecture of the Compendium started from the fall term of 1593 and ended in the spring term on 1595. Its first part De Sphera presents Earth as a globe based on the Tractatus de Sphaera by Johannes de Sacrobosco (1195-1236), who interprets Aristotle and Ptolemy's astronomy and the physics of four elements, air, water, fire, and earth. Part Two on anima is also based on Aristotle interpreted by Thomas Aquinas (1225-1274) (Gonoi 2012: 128). For Japanese, who are used to Buddhist transmigration of the soul that allows man's rebirth into an animal if he does not behave virtuously, the Aristotelian argument of anima that stratifies the plants, animals, and man must be easily acceptable as a reorganization of a familiar world.

A scholar of the eighteenth-century French encyclopedia, Jacques Proust writes that Jesuit fathers who came to Japan brought a comprehensive education of European Renaissance Humanism that is broader than Christianity. With the example of Cristóvão Ferreira, Proust counts the textbooks that Ferreira must have studied from 1596 when he entered the Society of Jesus in Coimbra at the age of sixteen to the time when he pursued his study 
in Goa in India, Lisbon in Portugal, and Arima in Japan (Proust 2013: 13). In all three countries, Ferreira was educated according to the general curriculum of Jesuit schools: three years of philosophy, logic, meteorology, physics, metaphysics, ethics, Aristotle's De anima, Euclidian mathematics, astronomy, cosmography, and the theology of Thomas Aquinas (ibid.: 35-36). If along with Cicero and Quintilian, Aristotle's Poetics was more popular than Aristotle's Rhetoric, this latter text was also taught in European Jesuit institutions in Latin translation (Douay-Soublin 1997). This curriculum overlaps with the disciplines covered by the aforementioned Compendium printed for the Japanese Jesuit colleges and also with Chiara's description. Proust points out that the rhetoric taught in Jesuit schools could be used by apostates for the refutation of Christianity (Proust 1997: 76). Primarily, rhetoric used for sermons and Mass helped Christian missionaries to refute Buddhism, but in some cases of apostasy, the same logic taken in a reverse gear was instrumental to refute Christianity. Proust's argument shows us that what the Society of Jesus brought to Japan was the whole package of their learning shaped in their particular historical time that includes rhetoric. This European way of conceiving the world spread in the doctrinal polemic with Buddhists and in the teaching of the sciences.

Young children learn their lessons and prayers by heart in blind repetition. In the Sumario, Valignano writes that since Latin and Japanese are so different the only way for Japanese to learn Latin adequately would be to start it when they are very young (Valignano 1990: 146). In June 1580, during his first visit to Japan, Valignano wrote Regimento que se ha de guarder nos semynarios, which determined the seminary curriculum (Schütte 1980: 346). The Seminario was open to the students of age seven to seventeen. How heavily the young children are imbued with Latin can be seen in the curriculum written in his Regimento. The day starts at 4:30; after the morning prayer, the young boys start learning by heart the Latin vocabulary from 6 to 7:30; from 7:30 to 9:00, they practice translation into Latin; after a recreation, from 11:00 to 2:00 they study to read and write Japanese; from 2:00 to 3:00 they receive music lessons; and from 3:00 to 4:30 they study Latin composition; after a recreation, from 7:00 to 8:00 they go back to Latin; and at 8:00 with a brief examination of conscience they go to bed (ibid.: 351-352). When Valignano came back to Japan in 1590 with the Tenshō Mission, he judged it necessary to change the seminary curriculum because the progress of Latin was not satisfactory (Gonoi 2012: 134). As a consequence, it was decided to teach Latin first and only after finishing the basic courses of Latin were students exposed to Japanese classics (ibid.: 136). The Seminario trained its pupils to become Japanese Jesuits who could guide the Japanese Church on their own one day.

On the other hand, in the church schools for the neighborhood children, the pupils also memorized easy Latin. Already in 1561 the first Jesuit primary school started in today's Ōita prefecture in the southern island of Kyūshū by Cosme de Torres, and in 1562 Luís de Almeida instituted another one in Yokoseura on the shore of Nagasaki in the same island. By 1583, the majority of about two hundred churches in Japan had primary schools (Shiling 1992: 57-58). In these local schools, too, the Latin language was implemented through prayers and songs. In letters written in the 1560s, the Jesuits Luis Frois and Giovanni Battista de Monte report that Japanese children learn by heart not only the catechism in Japanese, but also, in a fine Latin pronunciation, they can say prayers and sing psalms (Gonoi 2017: 152-153). In the typical curriculum, school started with the Mass and children recited the catechism and prayer. The recitation included "Pater Noster", "Ave Maria”, "Credo", 
and "Salve Regina" (Ebisawa [\&] Ōuchi 1971: 67). Some schools included a play before Nativity and some musical education with songs of psalms accompanied with instruments (Shiling 1992: 56-76). We cannot forget that for these children Latin was a living language, because they memorized the prayers as a part of their daily life, without always knowing the in-depth meaning as clergies do.

The Christian doctrine adapted to Japan, the establishment of a Church language with a good style of Japanese, the instruction in Latin, and the school curriculum in general created what William Farge S.J. calls the medieval sense of imitation. Japanese Christians respected the doctrinal form stipulated by the Catholic Church while adapting it to Japanese social and cultural conventions. Under the proscription, Christians had two choices, both of which are doctrinally correct: martyrdom or hiding. Yamamoto Hirofumi argues that the martyrs of the rank of bushi accepted to die for the heavenly master instead of dying with seppuku (cutting the belly) for their secular master (Asami 2009: 277). The meaning of lord may have changed, but the Japanese cultural mold persisted and fitted to the Christian form of martyrdom. Those who went into hiding practiced contrition and kept their sin on hold in waiting for the sacrament of forgiveness (ibid.: 341). The function of contrition is explained in the book Konchirisan no riyaku (Benefits of Contrition) written by Luis Cerqueira the Bishop of Japan, and published by the Jesuit Mission Press in 1603.

As for the book of martyrdom, the Sanctos no gosagvio published by the Jesuit Mission Press in 1591, it explained the exemplary lives of saints who died as martyrs. For instance, we read "To-day the Holy Church celebrates the victory gained by St. Peter and St. Paul" and "To-day's is the most important of Christian celebrations, because it is the day on which the chief captains of Christianity gained the victory" (Satow 1992: 6-7). The victory was "doubled" since Saint Peter and Saint Paul were celebrated the same day. Under Japanese law of that time, Japanese Christians were put on the cross for execution while the commoners executed for other reasons than Christianity were beheaded. Within this legal context, the Jesuit Mission Press published the complete Japanese translation of the book Imitatio Christi that preaches the imitation of Christ. The Sanctos no gosagvio reads: "St. Paul was a Roman, and therefore, in accordance with an ancient law, was decapitated. St. Peter, being a descendant of Judah, was hung on the cross, following the precedent of Our Lord Jesus Christ. For these reasons the Church to-day celebrates their memory." For Japanese who lived amid constant warfare during the period of the Warring State Period, the ephemeral nature of this world and man's life were not only familiar topoi of literature under Buddhist influence, but also lived experiences.

In 1790, the incident known as Urakami ichiban kuzure or first collapse at Urakami occurred. Lasting from 1790 to 1795 , the Urakami ichibankuzure was the first of four collapses of the solidarity that held together the secret league of Christians at Urakami. Fourteen hand-copied books and texts were confiscated at that time and preserved until 1896 when Dr. Murakami Naojirō (1868-1966) discovered them in Nagasaki Prefecture (Asami 2009: 256). The Christians of Urakami had three books of martyrdom (Gonoi 2012: 28-29). Among these three, the one entitled Maruchiriyo no susume (Recommendation of Martyrdom) is published in modern print by Hubert Cieslik S.J. with the title Maruchiru no michi (Way of Martyrdom) (Asami 2009: 265). This book recommends martyrdom without compromise. On the other hand, another of the three texts Maruchiriyo no kokoroe (What you need to know about martyrdom) explains in a clear and short text what the Japanese 
Christians should and should not do in order to avoid martyrdom: they cannot disguise themselves in Buddhist monk's attire to protect themselves, but they can hide their faith or stay silent about it (ibid.: 261). Hubert Cieslik S.J. speculates that this text was written in 1598 by Pedro Gomez who also wrote the Compendium catholicae veritatis, and Asami confirms Cieslik's opinion with his own demonstration (ibid.: 257, 285).

The book on martyrdom and the book on contrition are two types of texts that the senpuku kirishitan preserved. The senpuku kirishitan were in agreement with the doctrine left by the Jesuits of the Christian Century, but they adapted the notion of contrition to their own ways by inventing different ceremonies and prayers. Asami reminds us that the Jesuits encountered different concepts of God. For example, when the Japanese Christian doctrine was applied in China, it did not work as in Japan and created the Chinese Rites Controversy because China and Japan each had a different idea of God (ibid.: 343). By definition, in Christianity, God is one and universal. Therefore, I would rather argue that when Christianity spread to the non-Christian world, each region perceived God through its own set of linguistic and cultural conventions. The Society itself borrowed these alien forms of expression in places where Christianity was a minority, because, if not, they could not explain Christianity in a language understood by non-Christians. From the early period of their mission, the Jesuits reported with surprise how Japanese Christians show a strong attachment to rosary, veronica, and medals, and use them better than European Christians to express their faith (Gonoi 2017: 129-132). This veneration of the objects of devotion is consistent with the Japanese practice of expressing their way to sense the invisible being, in Shintoism and Buddhism. Japanese Christians tried to approach God from their familiar way of handling symbols for calling down God into objects. Miyazaki observes it in modern kakure kirishitan, with the kamiyose that calls God into man's world, and the o-tama-ire that blows spirit into objects, both in Shintoism (Miyazaki 2014: 84, 194). The Jesuits did not engage in polemic with Shintoism, but they encountered this oldest and only indigenous religion hidden in the expressive structure of Japanese religious faith.

A small book containing Latin prayers and psalms, in which the Latin language is transcribed into Japanese phonetic script, is preserved in the National Museum of Tokyo with the notice that it was confiscated when Hara Castle fell in the Shimabara Rebellion in 1638 (Gonoi 2017: 152). When Nagasaki was donated to the Society from 1580 to 1587, this town came under the Jesuit governance. From that time to the Shimabara Rebellion, two to three generations of children were brought up in Jesuit church schools; they naturally sang psalms and said their prayers in Latin, and these words were transmitted and recited as a part of their family life from parents to children for over seventy years (ibid.: 153). In Hara Castle in Shimabara, not far away from Nagasaki, the Christians barricaded themselves to attempt the largest battle of resistance against the governing shogun's army after the unification of Japan by the Tokugawas. In the past, peasant revolts were organized against the regional lords, but never against the national government. Therefore, the Shimabara Rebellion that squarely challenged the government forces was alarming in itself. From the ruins of the castle excavated in the twentieth century, archeologists found, along with many crosses and medals, an Ave Maria written in Latin transcribed in Japanese phonetic alphabet (ibid.: 135). The Latin songs, Christian objects of devotion, and fragments of Latin prayers transcribed in Japanese phonetic script remained persuasive tokens of their faith to the people who died in Hara castle during the siege of 1637 to 1638 . The number 
of Christians barricaded in Hara Castle varies from twenty to thirty-seven thousand, and the number of casualties in the government army was ten thousand nine hundred thirtyseven including one thousand six hundred forty deaths (Yokota 2002: 131). Japan closed the country to Christianity in 1639, and kept a narrow window open only to the Protestant Netherlands for trade but not for any Christian mission ${ }^{10}$.

In 1865, a French bishop Bernard Thaddée Petitjean of the Société des Missions Étrangères de Paris received a group of Japanese in his new Catholic church built for French people arriving in Japan after the treaties that the shogun's government signed with European countries from 1852 onward. They were Japanese Christians who came to his church. Subsequently, the unbelievable number of fifty thousand Christians turned up from the area around Nagasaki (Kōso 2013: 290-293). Petitjean published the documents and prayers of this community in a series of publications called the Petitjean Edition (Petitjean-ban) during the second half of the nineteenth century. Among the texts printed by Petitjean, there is a hand-copied book, based on the aforementioned guidebook of contrition, that Petitjean published under the new title Konchirisan no ryaku (Abridged Text of Contrition) in $1869^{11}$. Petitjean writes in his letter dated March 28, 1865 that the Japanese Christians came to his church and started prayers in Latin and Japanese (Petitjean 2015: 44). All basic prayers taught to the Japanese Christians were published in the Doctrina Christiana in 1591, a year after the arrival of the printing press from Europe (Gonoi 2017: 153). The spread of Latin prayers and their translation into Japanese show how the textbooks were used and varied by the senpuku kirishitan. The most representative prayer of Grace preserved by them since the Christian Century was still recognizable to Petitjean in 1865 so that he could restore the original Latin text (Miyazaki 2014: 98-101). These prayers lost their meaning as language in the course of time for those who were reciting them, but the material and acoustic presence of these documents, written or recited, acquired another meaning, similar to the objects of devotion like a cross and a medal, as a passing medium through which the follower of Christ reaches toward the invisible spirit.

The books published by the Jesuit Mission Press may have survived in ways unforeseen by their publishers of the sixteenth century. Nevertheless, Jesuit rhetoric was a success because, through these materially and orally preserved documents, Japanese Christians maintained those practices through which many successfully revived their faith and came back to Catholicism in the nineteenth century, with the sacraments of forgiveness administered by the qualified bishops of the Catholic Church, just as the Jesuits had written so many years earlier.

\footnotetext{
10 The location of Hara Castle, on the seashore, makes historians speculate today that the insurgent Christians may have been waiting for the Portuguese to rescue them, although no document confirms this (Yokota 2002: 128). Nagasaki was donated to the Society by the Christian warlord Ötomo Sumitada, who was supposedly in debt to the Society (Kudamatsu 2017: 174). The Society immediately transformed Nagasaki into a fort and armed it (Anno 2014: 121-122). When Toyotomi Hideyoshi confiscated Nagasaki from the Society and put it under his direct governance in 1587, he knew the military strength of the Society. In 1709, when Arai Hakuseki interrogated the last European Christian missionary in Japan, Giovanni Battista Sidoti, one of his purposes was to find out if this Italian father was not the forerunner of colonial forces planning to invade Japan. It was feared in Japan that by converting people to the Christian faith, Portugal and Spain facilitated their task of colonizing them. In the light of this preconception, which was confirmed by what happened in South Asia and in Latin America, the rebellion at Hara Castle looked like an invasion into people's heart and therefore an eminent danger to the Tokugawa shogun.

11 This book is republished in Petitjean-ban shūsei, volume 8, in 2012.
} 


\section{Bibliography}

Anno Masaki 2014. Kyōkairyō Nagasaki. Tōkyō: Kōdansha.

Arai Toshi 1973. "Junsatsushi Valignano-shi to kirishitan ban no shuppan". In: Kirishitan ban no kenkyū. Tenri, Japan: Tenri Central Library.

Asami Masakazu 2009. Kirisutokyō to gūzōsūhai. Tōkyō: Tōkyō Daigaku Shuppankai.

Barros, João 1539. Grammatica da lingua portuguesa com os mandamentos da santa madre igreja. Lisboa: em casa de Luiz Rodrigues.

Boxer, Charles 1967. The Christian Century of Japan 1549-1650. Berkeley: University of California Press.

Cieslik, Hubert S.J., Kamei Takashi [\&] Kojima Yukie 1983. Nihon Iezusukai-ban Kirishitan yōri. Tōkyō: Iwanami Shoten.

Douay-Soublin, Françoise 1997. "Les jésuites et l'autorité de la Rhétorique d’Aristote". In: Gilbert Dahan [\&] Irene Rosier-Catach (ed.). La Rhétorique d'Aristote, traditions et commentaires de l'Antiquité au XVIIe siècle. Paris: Vrin.

Ebisawa Arimichi [\&] Ōuchi Saburō 1971. Nihon Kirisutokyō shi. Tōkyō: Nihon Kirisutokyō-dan Shuppankyoku.

Farge, William J. S.J. 2002. The Japanese Translations of the Jesuit Mission Press, 1590-1614. Lewiston: The Edwin Mellen Press.

Gannett, Cinthia 2017. "Rhetoric(s) and Eloquentia Perecta". In: The Cambridge Encyclopedia of the Jesuits. Cambridge: Cambridge University Press.

Gonoi Takashi 2012. Kirishitan no bunka. Tōkyō: Yoshikawa Kōbunkan.

— 2017. Kirishitan daimyo. Kyōto: Miyaobi Shuppansha.

Kawai Tadanobu [\&] Muramoto Masato 1973. "Kirishitan-ban no shoshi kaisetsu". In: Kirishitan ban no kenkyū. Tenri, Japan: Tenri Central Library.

Kenkō or Yoshida Kaneyoshi 2013. Essays in idleness and Hōjōki. Tr. Meredith McKinney. London: Penguin Classics.

Kōso Toshiaki 2013. "Petitjean-ban”. In: Toyoshima Masayuki (ed.). Kirishitan to shuppan. Tōkyō: Yagi Shoten.

Kudamatsu Kazunori 2017. “Ōtomo Sumitada”. In: Gonoi Takashi (ed.). Kirishitan daimyo. Kyōto: Miyaobi Shuppansha.

Laures, Johannes 1936. "Nihon Yasokai kohanbon sanbu no hakken”. Toshokan zasshi, April.

Matsuda Kiichi 1973. Nanban no bateren. Tōkyō: NHK Books.

Miyazaki Kentarō 2014. Kakure kirishitan no jitsuzō. Tōkyō: Yoshikawa Kōbunkan.

-2018. Senpuku Kirishitan wa nani o shinjite itanoka. Tōkyō: Kōdansha.

Miyazaki Michio 1968. Shintei Seiyō kibun. Tōkyō: Heibonsha.

Murakami Naojirō 1926. "Nihon Yasokai kankōsho kaidai". In: "Nihon yasokai kankō shoshi" kaisetsu. Tōkyō: Keiseisha.

Nitta Ichirō 2001. Taiheiki no jidai. Tokyo: Kōdansha.

Orii Yoshimi 2013. "Taikō shūkyō kaikaku to senpuku kirishitan o kirishitan-ban de tsunagu". In: Toyoshima Masayuki (ed.). Kirishitan to shuppan. Tōkyō: Yagi Shoten.

Ōtsu Yūji 2017. “Ōtomo Sōrin, Yoshimune”. In Gonoi Takashi (ed.). Kirishitan daimyo. Kyōto: Miyaobi Shuppansha.

Petitjean, Bernard Thaddée 2015. 1865 Petitjean shokansh - genbun, honkoku, honyaku. Nagasaki: Nagasaki Junshin Daigaku Hakubutsukan.

Proust, Jacques 1997. L'Europe au prisme du Japon XVIe-XVIII siècle, Entre humanisme, Contre-Réforme et Lumières. Paris: Albin Michel.

Proust, Jacques 2013. La Superchérie dévoilée, nouvelle edition. Paris: Chandeigne.

Rodrigues, João 1955. Nihon daibunten. Transl. Doi Tadao. Tōkyō: Sanseidō. 
Satow, Ernest 1900. The Jesuit Mission Press in Japan. Yokohama: Asiatic Society of Japan.

— 1992. The Jesuit Mission Press in Japan 1591-1610. Tokyo: Keiseisha.

Schütte, Josef Franz, S.J. 1980. Valignano's Mission Principles for Japan, Part I: The Problem (1573-1580). Transl. John J. Coyne, S.J. St. Louis: The Institute of Jesuit Sources.

1983. Valignano's Mission Principles for Japan, Part II: The Solution (1580-1582). Transl. John J. Coyne, S.J. St. Louis: The Institute of Jesuit Sources.

Shiling, Drotheus 1992. Nihon ni okeru Yasokai no gakkōseido. Tr. Yoshitomo Okamoto. Tōkyō: Ōzorasha.

Tani Shinsuke 2014. Santa Maria no gozō wa doko. Tōkyō: Joshi Paulo-kai.

Tenri Toshokan 1973. Kirishitan ban no kenkyū. Tenri: Tenri Central Library.

Toyoshima Masayuki (ed.) 2013. Kirishitan to shuppan. Tōkyō: Yagi Shoten.

Valignano, Alessandro 1990. Les jésuites au Japon, Relation missionnaire (1583). Tr. J. Bésineau S.J. Paris: Desclée de Brouwer.

Wakao Masaki 2003. "Kyōhō-Tenpō ki no shakai to bunka”. In: Ōishi Manabu (ed.). Kyōhō kaikaku to shakai henyō. Tōkyō: Yoshikawa Kōbunkan.

Xavier, Francis 1992. Letters and Instructions of Francis Xavier. Tr. M. Joseph Costelloe, S.J. Saint Louis: The Institute of Jesuit Sources.

Yagi Sōichi 2013. "Kirishitan-ban "Nabarusu no zange" hakken tenmatsu". In: Toyoshima Masayuki (ed.). Kirishitan to shuppan. Tōkyō: Yagi Shoten.

Yokota Fuyuhiko 2002. Tenka taihei. Tōkyō: Kōdansha. 